\title{
Consumer
}

\section{attitudes towards nanotechnologies applied to food production}

\author{
L.J. Frewer ${ }^{a, *}$, N. Gupta ${ }^{b}$, \\ S. George ${ }^{C}$, A.R.H. Fischer ${ }^{b}$, \\ E.L. Giles ${ }^{d}$ and D. Coles ${ }^{a, e}$
}

${ }^{\mathrm{a}}$ Food and Society Group, School of Agriculture, Food and Rural Development, Newcastle University, Newcastle Upon Tyne NE1 7RU, UK (Tel.: D44 (0) 191 2088272; e-mail:

Lynn.Frewer@Newcastle.ac.uk) ${ }^{\mathrm{b}}$ Marketing and Consumer Behaviour Group, Wageningen University, 6706 KN Wageningen, The Netherlands ${ }^{\mathrm{C}}$ Centre for Sustainable Nanotechnology, School of Chemical and Life Sciences, Nanyang Polytechnic, 180 Ang Mo Kio Avenue 8, Singapore 569830, Singapore ${ }^{d}$ Institute of Health and Society, BaddileyClark Building, Newcastle University, Newcastle Upon Tyne NE2 4AX, UK ${ }^{\text {e University of Central }}$ Lancashire, Preston, Lancashire, PR1 2HE, UK

The literature on public perceptions of, and attitudes towards, nanotechnology used in the agrifood sector is reviewed. Research into consumer perceptions and attitudes has focused on general applications of nanotechnology, rather than within the agrifood sector. Perceptions of risk and benefit associated with different applications of nanotechnology, including agri-food applications, shape consumer attitudes, and acceptance, together with ethical concerns related to environmental impact or animal welfare. Attitudes are currently moderately

* Corresponding author. positive across all areas of application. The occurrence of a negative or positive incident in the agri-food sector may crystallise consumer views regarding acceptance or rejection of nanotechnology products.

\section{Introduction}

Understanding the socio-cultural and historical contexts which determine people's attitudes to, and acceptance of, emerging technologies, and their applications, is now rec-ognised by stakeholders in academia, industry and policy communities as being an important determinant of their successful implementation and commercialisation (e.g. Cardello, 2003; Gupta, Fischer, \& Frewer, 2012; Lowe, Phillipson, \& Lee, 2008). Nanotechnology applied within the agri-food sector is not exceptional in this regard (Neethirajan \& Jayas, 2011; Roco, 2003). However, at the time of writing, the focus of the literature on societal accep-tance of agri-food nanotechnology is much more limited in comparison to that associated with earlier, controversial agri-food technologies, in particular the application of Ge-netic Modification (GM) to food production (Costa-Font, Gil, \& Traill, 2008; Frewer et al., 2013). The aim of this re-view is to map issues associated with consumer perceptions of, and attitudes towards, technology applied to agri-food production, to contextualise this by reviewing what is known about consumer perceptions of, and attitudes to-wards, nanotechnology applied to agri-food production in particular, and to extrapolate to existing and emerging ex-amples of nanotechnology applied in the agrifood sector.

It has been argued by various academics and other key stakeholders that the application of agrifood technologies as such may not automatically be rejected by the public, but that societal acceptance or rejection of specific applica-tions is shaped by the way the specific characteristics of agrifood technology applications are viewed in relation to the values held by members of society. This may include, inter alia, the extent to which applications are perceived to be risky or beneficial, either to individuals or society as a whole (e.g. Alhakami \& Slovic, 1994; Eiser, Miles, \& Frewer, 2002; Frewer, Bergmann, et al., 2011; Frewer, Norde, Fischer, \& Kampers, 2011; Gaskell et al., 2004), and the extent to which the regulatory context in which the technology is embedded promotes legislation and governance practices which optimise consumer and envi-ronmental protection (e.g. Cvetkovich, 2013; Lang \& 
Please cite this article in press as: Frewer, L. J., et al., Consumer attitudes towards nanotechnologies applied to food production, Trends in Food Science \& Technology (2014), http://dx.doi.org/10.1016/j.tifs.2014.06.005 
Hallman, 2005). An added level of complexity regarding the acceptance of emerging agri-food technologies is pro-vided by dynamic socio-cultural shifts in societal values, for example, emerging consumer preferences for environmentally friendly production systems, (Kriwy \& Mecking, 2012), localised food production, (e.g. Hingley, Mikkola, Canavari, \& Asioli, 2012), and improved animal welfare standards (Lagerkvist \& Hess, 2011; although see Harvey \& Hubbard, 2013), which makes it difficult to create a long term commercialisation trajectory for a new agrifood technology based on existing influential societal values. Nevertheless, if novel agrifood technologies are perceived by consumers to act against their existing preferences, (for example, through negative impacts on the environment, increased globalisation of the food supply or compromised animal welfare standards), or if consumers perceive that they have been unknowingly exposed to risky or unethical food risks associated with innovations in agricultural production, (Frewer \& Salter, 2002), then acceptance of products may be problematic.

In this context, various societal drivers influence how and when technologies are applied to agri-food production, independent from, or even opposed to, currently dominant consumer values. Increased concerns about local, regional and global food and nutrition security (e.g. Godfray et al., 2010; Misselhorn et al., 2012; Subramanian, Kirwan, \& Pink, 2010), have highlighted the need to opti-mise supply and demand of food commodities at a global rather than local scale. This concern arises in a world where climate change, growth in populations, and socio-demographic changes such as urban migration, and increased average age of populations, place further de-mands on food supply. Technological as well as social inno-vation is required if food security is to be delivered to an increasing global population (Ingram, Gregory, \& Izac, 2008). Integrating nanotechnological innovation with soci-etal preferences and priorities for food security solutions may be of benefit in this regard (Frewer, Bergmann, et al., 2011; Frewer, Norde, et al., 2011). A case in point, in affluent societies in particular, the demand for functional foods and ingredients, which can more precisely focus nutritional needs to the health requirements of the individ-ual, are a priority for some population segments (e.g. Bech-Larsen \& Scholderer, 2007; Schmidt, 2000), and this may increase demand for foods which are produced using nano-technology which confer health benefits. At the same time, the adoption of "postproductivist" values appears to be a widespread reaction to the green revolution and subsequent developments in monoculture, high-input technologies, have been described as the industrialisation of agriculture in the second half of the last century (Coles et al., in preparation). The postproductivist rural economy is char-acterised by reductions in food output, and progressive withdrawal of state subsidies for agriculture, together with differential land use, a focus on a more sustainable agricultural system, animal welfare, environmental balance and a more local and regionally based approach to production. Such developments in agriculture are accompanied by a more diverse, structured and rigorous regulatory system with increased environmental regulation of agriculture and greater consumer engagement at all stages of the food-chain. This is particularly relevant in relation to issues of food quality, safety, and choice (Burchart, 2007; Burton \& Wilson, 2006; Ilbery \& Kneafsey, 1998; Lowe, Murdoch, Marsden, Munton, \& Flynn, 1993). Technological innovation in the agrifood sector must, refocus on the develop-ment of foods and food commodities that deliver specific benefits in line with stakeholder and consumer expecta-tions, as well as deliver adequate, safe and nutritious food.. Within this context, consumer priorities and prefer-ences regarding the development and implementation of previous agrifood technologies represents an important consideration in shaping how agrifood process and products are developed (Griffin \& Hauser, 1993; Gupta, Fischer, van der Lans, \& Frewer, 2012; Raley, Ragona, Sijtsema, Fischer, \& Frewer, submitted for publication; Ronteltap, Fischer, \& Tobi, 2011; Van Kleef, van Trijp, \& Luning, 2005).

Furthermore, as has been demonstrated by the case of GM foods, the extent to which people perceive these foods to be unnatural, and have ethical concerns about technology as "tampering with nature", are associated with higher risk perceptions and lower perceptions of benefit (Bredahl, 2001; Costa-Font et al., 2008; Fife-Schaw \& Rowe, 1996; Frewer, Howard, \& Shepherd, 1997, Frewer et al., 2013; Knight, 2009; Mather et al., 2011). This may be linked to the societal perception that any negative and unintended biological effects were irreversible once living GM organ-isms were released into the environment, as "unnatural" traits could potentially be conferred on "descendant" organ-isms (Torgersen, 2009). The societal response towards GM foods has been frequently posited as representing the normative societal response to any technological innovation in the agrifood sector. However, some recently imple-mented food technologies, such as high pressure processing or other cold food preservation technologies (Nielsen et al., 2009; Sorenson \& Henchion, 2011) have been accepted by both society in general and consumers, with little societal discussion of their merits or otherwise (Frewer, Bergmann, et al., 2011; Frewer, Norde, et al., 2011). Whilst several authors have conducted comparative reviews of research focused on consumer perceptions of, and attitudes towards, technologies applied to agrifood production, including nanotechnology, these have failed either to consider agrifood nanotechnology in detail (being focused on gene technologies applied to food production, where there are more data available (e.g. Gupta, Fischer, \& Frewer, 2012), or have discussed generic attitudes towards food technologies rather than nanotechnology specifically (e.g. Synergist, 2008), or have failed to consider the factors underpinning the lack of current societal discourse regarding agri-food nanotechnology relative to other, 
\& Technology (2014), http://dx.doi.org/10.1016/j.tifs.2014.06.005 
earlier, controversial food technologies, which is observable at time of writing (e.g. Frewer, Bergmann, et al., 2011; Frewer, Norde, et al., 2011; Gupta, Fischer, \& Frewer, 2012; Rollin, Kennedy, \& Wills, 2011; Siegrist, 2008) or have been confined to European research (Rollin et al., 2011).

\section{Extrapolating from other examples of emerging technology applied to agrifood production}

It has also been argued that lessons from mistakes made when agrifood technologies were introduced have facilitated the identification of factors which will result in societal acceptance or rejection of subsequent technologies (David \& Thompson, 2011; Kuzma \& Priest, 2010). However, there is more research regarding focused on why agrifood applications have been rejected than that seeking to explain what factors determine acceptance. This may be because research sponsors fund research into social responses to technologies after a particular technology or application had been rejected, rather than prior to its introduction and commercialisation (Frewer, Bergmann, et al., 2011; Frewer, Norde, et al., 2011). The features or characteristics of the application which will lead to acceptance have not been identified before the product has been commercialised, or incorporated into the design of the product. Furthermore, societal and cultural values are not static, but are co-determined by socio-economic and biophysical factors, which are continually changing. Thus the relative (lack of) consumer debate associated with consumer accep-tance of nanotechnology may relate to changes in cultural values between the mid 1990's, when the first GM agricul-tural applications were introduced, and the present time, when nanotechnology applied to food production is ready for commercialisation.

Food products developed using nanotechnology will be increasingly made available to consumers. Consumer perceptions and attitudes will be important determinants of their commercial success or failure. An overview of the research focused on public perceptions of, and attitudes to-wards, both general applications of nanotechnology, and agrifood related applications specifically, may contribute to understanding future consumer responses to agrifood applications of nanotechnology.

\section{Public attitudes towards nanotechnology as an enabling technology}

A limitation of the existing literature focused on public perceptions of nanotechnology is that it has tended not to focus on specific applications (Berube, Cummings, Frith, Binder, \& Oldendick, 2011; Cacciatore, Scheufele, \& Corley, 2011; Cobb, 2005; Gaskell et al., 2004; Lee, Scheufele, \& Lewenstein, 2005; Macoubrie, 2004; Pidgeon, Harthorn, \& Satterfield, 2011; Reisch, Scholl, \& Bietz, 2011; Scheufele \& Lewenstein, 2005; Sheetz, Vidal, Pearson, \& Lozano, 2005). It is recognised that risk benefit perceptions, rather than risk perceptions alone, may determine how consumers respond to different nanotechnology related applications (Burri, 2007; Conti, Satterfield, \& Harthorn, 2011; Retzbach, Marschall, Rahnke, Otto, \& Maier, 2011; Sheetz et al., 2005; Smith, Hosgood, Michelson, \& Stowe, 2008), although how consumers "trade off" such perceptions when making decisions about specific products developed using nanotechnology is less well understood. In general, the literature suggests that, overall, public attitudes towards nanotechnology tend to be somewhat positive, and that the perceived benefits of nanotechnology tend to outweigh the perceived risks (Burri \& Bellucci, 2008; Priest \& Greenhalgh, 2011; Satterfield, Kandlikar, Beaudrie, Conti, \& Harthorn, 2009; Scheufele \& Lewenstein, 2005; Stampfli, Siegrist, \& Kastenholz, 2010).

Public perceptions of, and attitudes towards, nanotechnology arise within the context of the society in which they are embedded, even if public knowledge about under-lying scientific processes is incomplete. It has been argued that support for nanotechnology will increase as public awareness of the science itself increases (Vandermoere, Blanchemanche, Bieberstein, Marette, \& Roosen, 2011), but this is not supported by empirical analysis of the im-pacts of information interventions (Fischer, van Dijk, de Jonge, Rowe, \& Frewer, 2013; Kahan, Braman, Slovic, Gastil, \& Cohen, 2009). Provision of information about nanotechnology may influence the attitudes held by different (groups of) individuals in different ways. For example, providing people with "balanced" information about the risks and benefits of nanotechnology results in some individuals becoming more positive, others more negative (Kahan et al., 2009). However, many people remain "ambivalent", holding neither positive or negative information, after receiving balanced information (Fischer et al., 2013). Ambivalence is generally experienced as unpleasant by those experiencing it (van Harreveld, Rutjens, Schneider, Nohlen, \& Keskinis, 2014). As a consequence, people will tend to shift their attitudes towards nonambivalence through the selection of information that strengthens their attitude in one direction only (Nordgren, van Harreveld, \& van der Pligt, 2006). One interpretation is that the current level of ambivalence reported by con-sumers may be a consequence of the limited number of products commercially available (or which can be identi-fied as being produced using nanotechnology in the absence of labelling). This means that making decisions about the acceptability or otherwise of products is not necessary, and so an ambivalent position can be maintained. An alter-native interpretation is that ambivalence may indicate that there are potentially unresolved social issues associated with nanotechnology (Rogers-Brown, Shearer, \& Harthorn, 2011), which makes the formation of a nonambivalent attitude difficult. Thus the introduction of prod-ucts developed using nanotechnology may "trigger" posi-tive or negative attitudes (depending on the extent to which consumers perceive that there are risks or benefits 
Please cite this article in press as: Frewer, L. J., et al., Consumer attitudes towards nanotechnologies applied to food production, Trends in Food Science \& Technology (2014), http://dx.doi.org/10.1016/j.tifs.2014.06.005 
associated with specific exemplars). Alternatively a high profile media event may also influence attitudes in either a positive or negative direction, depending on what has occurred and how this is interpreted by consumers (Frewer et al., in press).

The media has been found to be influential in informing, engaging and influencing public opinions associated with nanotechnology (Donk, Metag, Kohring, \& Marcinkowski, 2012; Groboljsek \& Mali, 2012; Ho, Scheufele, \& Corley, 2011; Metag \& Marcinkowski, 2013; Scheufele \& Lewenstein, 2005; Sch€utz \& Wiedemann, 2008). The importance of information pro-vided by the media may allow the use of cognitive shortcuts or heuristics and trust in scientists in shaping public opinion about nanotechnology (Scheufele \& Lewenstein, 2005; Smith et al., 2008).

Public attitudes towards science and technology in gen-eral may also be important predictors of peoples views (Retzbach et al., 2011; Scheufele \& Lewenstein, 2005). There is also evidence to suggest that attitudes toward tech-nologies that have already been introduced may influence the perceived benefits associated with different applications of nanotechnology (Stampfli et al., 2010). Similarly, reli-gious beliefs, and moral concerns may influence consumer acceptance of science and technology, and their applica-tions (Brossard, Scheufele, Kim, \& Lewenstein, 2009; Scheufele, Corley, Shih, Dalrymple, \& Ho, 2009). Trust in industry (Siegrist, Cousin, Kastenholz, \& Wiek, 2007) and/or governmental intuitions with regulatory responsibil-ity (Macoubrie, 2006) has also been found to influence pub-lic acceptance of nanotechnology, such that the greater the trust placed in industry or governmental institutions respon-sible for innovation and regulation, the more likely the pub-lic will be to accept the application of nanotechnology. Perceptions that social justice is being served, and the vulnerable are being protected, have also found to influence risk perceptions associated with nanotechnology (Conti et al., 2011). A question arises as to whether differences in consumer perceptions and attitudes exist in the devel-oped, as opposed to developing, world. The potential importance of active societal and consumer participation in product development and commercialisation associated with nanotechnology has been noted as being relevant for both the developed and developing world, although the out-puts of such participation may be contextualised by local circumstances (Burgi \& Pradeep, 2006). Optimism regarding the application of nanotechnology in general has been reported in Iran (Farshchi, Sadrnezhaad, Nejad, Mahmoodi, \& Abadi, 2011). Similar results were reported for high school students (Sahin and Ekli (2013) and adults (Senocak, 2014) in Turkey. In India, which has invested in nanotechnology, however, there is little activity focused on understanding public attitudes and priorities, despite exten-sive scientific research activity being conducted (Jayanthi, Beumer, and Bhattacharya (2012). Whilst there is no evi-dence to suggest that there is a systematic difference in attitudes between consumers developed and developing countries, more research is needed to establish if the putative benefits of application are perceived to be more substantial in less affluent countries.

\section{Public attitudes towards nanotechnology applied in the agrifood sector}

Of direct relevance to discussion of agrifood applications of nanotechnology is the observation that that the perceived characteristics of different types of nanotechnology application may differentially influence acceptance. For example, Priest and Greenhalgh (2011) reported that most future benefits anticipated by participants were in the areas of medical advances, rather than in other areas of application such as agrifood production. Conti et al. (2011) studied risk perceptions associated with nanotech-nology across different areas of sectorial application (en-ergy production, food production, and medical application) and demonstrated that food-related applica-tions of nanotechnology are most likely to raise societal concern when compared to other applications. For different areas of application, different ways of framing or imple-menting the technology may be needed to mitigate con-cerns specific to particular application areas (te Kulve \& Rip, 2013).

The factors which drive consumer acceptance may differ from those posited as relevant by experts in the area. Gupta (2013) compared expert and consumer opinions of what factors will drive societal acceptance or rejection of different applications of nanotechnology, including agri-food applications. In comparison to experts (Gupta, Fischer, George, \& Frewer, 2013; Gupta, Fischer, van der Lans, et al., 2012), consumers emphasised the importance of ethical concerns as a determinant, or otherwise, of accep-tance of specific products, but had less concern regarding potential physical contact with the product when compared to what had been predicted by experts. Similarly consumers were less concerned about foodrelated applications of nanotechnology than expert predictions of consumer concern indicated. However, under circumstances where research had initially been framed by questions directly asking about risk, both consumers and experts were more concerned about risks when compared to the results of research where such framing had not been included in the research design (Gupta, 2013). Despite such framing, con-sumers perceived food and medical applications to be the most useful and necessary applications of nanotechnology. Some crosscultural analyses have been conducted. For example, Liang et al. (2013) report that Singaporean citi-zens appear more familiar with nanotechnology than those in the US, and perceive greater benefit and less risk to be associated with it. It is arguable that nanotechnology applied to food production (for example, in order to in-crease food security) may be more valued by consumers in countries where there is greater perceived need. As is the case in affluent countries, data regarding consumer 
attitudes towards nanotechnology applied to agrifood is not extensive. An example includes a study examining attitudes towards nanotechnology used in food and food packaging in Mexico (L_opez-V_azquez, Brunner, \& Siegrist, 2012) which reported little evidence that consumer attitudes differed between the two countries. Overall, there is insufficient information available to systematically compare consumer attitudes in developed and developing economies.

Some attitude research has focused specifically on the application of nanotechnology in the agrifood sector. Food packaging which utilises nanotechnology has frequently been reported as being perceived to be more beneficial than foods which similarly utilises nanotech-nology (Siegrist et al., 2007; Siegrist, Stampfli, Kastenholz, \& Keller, 2008). However, cultural differentia-tion regarding the acceptability of packaging to consumers has also been identified. For example, French consumers are more reluctant to accept food packaging utilising nanotechnology, whereas German consumers are less inclined to accept food fortification achieved using similar technological innovations (Bieberstein, Roosen, Marette, Blanchemanche, \& Vandermoere, 2013). The issue of perceived benefit is, as has been discussed, important. However, while health benefits being associated with foods produced using nanotechnology appear to increase consumer acceptance, consumers may not be willing to pay more for these benefits (Marette, Roosen, Bieberstein, Blanchemanche, \& Vandermoere, 2009). Perceptions that foods produced by nanotechnology are in some way "tampering with nature" (Chun, 2009) provokes comparisons with public perceptions of GM foods (Frewer et al., 2013). Indeed, the association between the food produced using nanotechnology and GM-food is often made by experts (Gupta, Fischer, van der Lans, et al., 2012). Newspaper coverage of agrifood nanotechnology is relatively modest in terms of frequency of reporting, the thematic diversity of reporting, and the level of journalistic expertise from which it was produced (Dudo, Choi, \& Scheufele, 2011). A sudden increase in media reporting of the risks or benefits of foods produced using nanotechnology may rapidly crystallise consumer attitudes. The impact of communication via social media is less well understood (Rutsaert in press, 2013).

Taken together, this suggests that care should be taken not to oversimplify or underestimate the complexity of factors affecting consumer acceptance of agrifood nanotechnology. Issues related to social trust, the relative position of stakeholders and institutions regarding the development and application of nanotechnology, and human and environmental health risks and how these are perceived, are "dynamic, complex, interactive, and interdependent" (Yawson \& Kuzma, 2010).

\section{Ethical considerations within society}

Ethical and moral considerations have been shown to influence public acceptance of novel food technologies (e.g. Swierstra \& Rip, 2007), and nanotechnology is no exception to this (Coles \& Frewer, 2013; Grunwald, 2005). The ethical basis for future consideration of nanotechnology applied to foods has been considered elsewhere (Coles \& Frewer, 2013). In summary, the basic ethical principles of beneficence, non-malfeasance, justice and autonomy readily map across to important governance issues of benefit, risk, choice and the differential accruement of risk and benefit (see Table 1).

Due consideration of ethical issues, and how these are perceived by (different segments of) society is not only required as an integral part of the governance process, but must also be considered by scientists, producers and manufacturers as part of a responsible research and innovation approach (von Schomberg, 2013).

Table 2 provides examples of different applications of nanotechnology which may be associated with consumer perceptions of risk, benefit, and ethical concern.

\section{Discussion}

The current (lack of) consumer debate associated with agrifood nanotechnology may be a consequence of (some of) the following.

Technological innovation applied to food production per se is not societally unacceptable. Rather (perceived) characteristics of specific technologies, or their 
Table 1. The relation between governance and ethical principles associated with the application of nanotechnology.

Governance issue

Identification of Benefits associated with the (specific) application of nanotechnology

Identification of the Risks associated with the (specific) application of nanotechnology

Differential accruement of risk and benefit associated with a (specific application of) nanotechnology to different stakeholders or groups in the population End-users, consumers or other stakeholders can choose whether to adopt, be exposed to, or utilise (a specific application of) nanotechnology
Ethical principle

Beneficence: Any identifiable benefits associated with the technology application

NoneMalfeasance: The requirement to do no harm or at the very least minimise harms

Justice or fairness: Distribution of risk and benefit such that benefits do not accrue to one stakeholder while another bears the bulk of the risk

Autonomy: End-users, consumers or other stakeholders are provided with sufficient information and freedom to enable them to decide whether or not they wish to adopt or make use of nanotechnology applications in the food chain. application, or how these are regulated, may potentially be drivers of societal negativity. Thus the application of

\section{(some) consumers}

It is too early in the implementation trajectory for societal negativity associated with specific applications of agri-food nanotechnology to have arisen, as consumers are not familiar with either nanotechnology or its application within the area of agriculture or to the human food chain

Lessons from the application of GM food technologies have been implemented by regulators and industry in the case of nanotechnology, which has resulted in increased acceptance of agrifood applications by consumers.

The first argument assumes that consumers evaluate the characteristics of all technologies, including those applied in the agri-food sector, against similar criteria. There is some evidence that consumers perceive risks and other con-cerns to be associated with nanotechnology when applied in the agrifood sector. However, this may, in part, be a methodological artefact, as consumers do not spontaneously raise the issue of risk in the context of agrifood applications of nanotechnology (Gupta, 2013). People's concerns focus on specific application areas rather than the technology be-ing utilised to produce that application. For example, nega-tive consumer attitudes associated with "smart pesticides" focus on the issue of pesticide use (in line with the values promoted in a post-productivist society) rather than on the issue of nanotechnology being applied (Gupta, 2013). Consumer rejection of GM foods may be technologically specific and not generalise to other agrifood technologies. A case in point, GM appears to be associated with percep-tions that environmental impacts are potentially irreversible as living organisms are involved. In comparison, nanotech-nology may be perceived to be potentially amenable to mitigation strategies should unintended or intended envi-ronmental releases of nanomaterials occur, and negative environmental impacts result.

The second argument, that it is too early in the implementation trajectory for consumer attitudes towards specific applications of agrifood nanotechnology to have crystallised, is potentially valid. At the present time, food and agricultural applications of nanotechnology are largely unidentifiable by consumers, if already on the market, and are relatively scarce compared to other sectors such as cosmetics application as (DeLouise, 2012; Raj, Jose, Sumod, \& Sabitha, 2012). This may be because of expert reticence to launch agrifood products which they perceive may be rejected by consumers (Frewer, Bergmann, et al., 2011; Frewer, Norde, et al., 2011; Gupta et al., 2013). At the same time, there has been limited coverage of nanotech-nology in general and nanotechnology agrifood production in particular, in contrast to that associated with GM foods (e.g. see Frewer, Miles, \& Marsh, 2002; Pidgeon et al., 2003; Scheufele et_al 2007). The occurrence of a high-profile event, in particular one which is perceived by the 
public to be potentially risky and to have been hidden to protect the vested interests of industries or institutions, or one which is associated with little societal or consumer benefit, may rapidly amplify societal negativity towards agrifood nanotechnology, and might impact on nanotechnology applied in other sectors.

The third argument, that lessons learned from the societal introduction of GM (in particular applied to the agrifood sector), have been applied to the introduction of agrifood nanotechnology. (Gupta, 2013). One result is that the food industry is reluctant to introduce advanced technologies, which makes it difficult to monitor consumer responses to specific products as these are not widely available to con-sumers. Against this, the mandatory labelling of consumer cosmetics within Europe has resulted in very little societal response (European Commission, 2012 ${ }^{1}$ ), perhaps because consumers can choose whether or not to buy specific prod-ucts, and the benefits of this particular sectoral utilisation of nanotechnology have been tailored to the needs of those consumers most receptive to them. As has been noted, con-sumer rejection of 1st generation GM foods has been linked directly to the lack of personal and societal benefits perceived to be relevant to consumers. Understanding what benefits consumers want from foods produced using nano-technology, and developing concomitant products, will ensure new technological developments and applications align with societal responses.

Indeed, various policy documents have identified the need for public engagement in relation to the development and implementation of emerging technologies (Renn \& Roco, 2006; Royal Society and Royal Academy of Engineering, 2004; Stemerding \& Rerimassie, 2013). The rationale for effective stakeholder, expert and public inputs into the research and development, commercialisation and policy process associated with emerging technologies has been established (e.g. Powell \& Colin, 2008; Renn \& Roco, 2006), although the lack of policy impact associated with such engagement has also been recognised as prob-lematic. For example, various authors (e.g. Glasner, 2002; Petts, 2008; Rowe \& Frewer, 2005), have noted that there is a lack of evidence demonstrating that public trust in pol-icy and policy making institutions is increased as a result of public engagement. Others (e.g. Kenyon, 2005) suggest that there is a lack of generalizability of results across a broad policy issue (for example, in the context of agri-food nanotechnology and its regulation). Given that public engagement has tended to be applied prior to technological introductions, rather than subsequent to their application (Delgado, Kjølberg, \& Wickson, 2011; Macnaghten, Kearnes, \& Wynne, 2005), the issue of policy impact (and how this is assessed) remains.

${ }^{1}$ http://ec.europa.eu/dgs/health_consumer/dyna/enews/enews.cfm?al_ id $1 / 41276$, Accessed 07.04.14. 


\section{Conclusions}

An important part of consumer acceptance of agrifood nanotechnology is societal inclusivity in the process of product design, development, and commercialisation of different applications. There are many ways to collate in-formation about societal preferences and priorities, for example through qualitative and quantitative research which can be applied to "fine-tune" the final delivery of different applications to the consumer. In terms of regula-tion and governance, it is important to ensure that the out-puts of public engagement and consultation, as well as expert and stakeholder preferences and priorities, are explicitly addressed in the development of regulatory and governance strategies. Ethical issues and concerns cannot be ignored in policy development. It may also be important to assess consumer responses to the first generation of prod-ucts developed. The development of these principles are a consequence of lessons from the GM debate, and can be adapted to take account of specific characteristics of nano-technology which may not generalise to the development and application of all enabling technologies. Various ques-tions need to be asked of agrifood applications of nanotech-nology (and indeed other enabling technologies) applied in agri-food production and their applications during the im-plementation and commercialisation process. These are:

Do the applications to the agrifood sector meet a recognised societal or consumer need?

What similarities with potentially societally controver-sial aspects of previously applied agrifood technologies can be identified?

Are additional issues raised over and above those associated with other enabling technologies applied to food production?

How can benefits and risks be equitably be distributed across all stakeholders?

What needs to be done to fine tune the development and implementation of agrifood applications of nanotechnol-ogies to align with consumer priorities, adoption and commercialisation of specific applications?

\section{References}

Adame, D., \& Beall, G. W. (2009). Direct measurement of the constrained polymer region in polyamide/claynanocomposites and the implications for gas diffusion. Applied Clay Science, $42,545 \mathrm{e} 552$

Akagi, T., Masanori, B., \& Mitsuru, A. (2012). Biodegradable nanoparticles as vaccine adjuvants and delivery systems: regulation of immune responses by nanoparticle-based vaccine. In S. Kunugi, \& T. Yamaoka (Eds.). Polymers in Nanomedicine, Vol. 247 (pp. 31e64). Springer Berlin Heidelberg.

Alhakami, A. S., \& Slovic, P. (1994). A psychological study of the inverse relationship between perceived risk and perceived benefit. Risk Analysis, 14(6), 1085e1096.

Bech-Larsen, T., \& Scholderer, J. (2007). Functional foods in Europe: consumer research, market experiences and regulatory aspects. Trends in Food Science \& Technology, 18(4), 231e234.
Berube, D. M., Cummings, C. L., Frith, J. H., Binder, A. R., \& Oldendick, R. (2011). Comparing nanoparticle risk perceptions to other known EHS risks. Journal of Nanoparticle Research, 13(8), 3089e3099.

Bieberstein, A., Roosen, J., Marette, S., Blanchemanche, S., \& Vandermoere, F. (2013). Consumer choices for nano-food and nano-packaging in France and Germany. European Review of Agricultural Economics, 40(1), 73 e94.

Bredahl, L. (2001). Determinants of consumer attitudes and purchase intentions with regard to genetically modified foods e results of a cross-national survey. Journal of Consumer Policy, 24(1), 23e61.

Brossard, D., Scheufele, D. A., Kim, E., \& Lewenstein, B. V. (2009). Religiosity as a perceptual filter: examining processes of opinion formation about nanotechnology. Public Understanding of Science, 18(5), 546e558.

Burchart, J. (2007). Agricultural history, rural history, or countryside history? The Historical Journal, 50(2), 465e481.

Burgi, B. R., \& Pradeep, T. (2006). Societal implications of nanoscience and nanotechnology in developing countries. Current Science, 90(5), 645e658.

Burri, R. V. (2007). Deliberating risks under uncertainty: experience, trust, and attitudes in a Swiss nanotechnology stakeholder discussion group. NanoEthics, 1(2), 143e154.

Burri, R. V., \& Bellucci, S. (2008). Public perception of nanotechnology. Journal of Nanoparticle Research, 10(3), 387e391.

Burton, R. J., \& Wilson, G. A. (2006). Injecting social psychology theory into conceptualisations of agricultural agency: towards a post-productivist farmer self-identity? Journal of Rural Studies, 22(1), 95e115.

Cacciatore, M. A., Scheufele, D. A., \& Corley, E. A. (2011). From enabling technology to applications: the evolution of risk perceptions about nanotechnology. Public Understanding of Science, 20(3), 385e404.

Cardello, A. V. (2003). Consumer concerns and expectations about novel food processing technologies: effects on product liking. Appetite, 40(3), 217e233.

Chaudhry, Q., Scotter, M., Blackburn, J., Ross, B., Boxall, A., Castle, L., \& Watkins, R. (2008). Applications and implications of nanotechnologies for the food sector. Food Additives \& Contaminants: Part A, 25(3), 241e258. http://dx.doi.org/10.1080/ 02652030701744538.

Chinnamuthu, C. R., \& Boopathi, P. M. (2009). Nanotechnology and agroecosystem. Madras Agricultural Journal, 96(1e6), 17e31.

Chun, A. L. (2009). Will the public swallow nanofood? Nature Nanotechnology, 4(12), 790e791.

Cobb, M. D. (2005). Framing effects on public opinion about nanotechnology. Science Communication, 27(2), 221e239.

Coles, D., \& Frewer, L. J. (2013). Nanotechnology applied to European food productioneA review of ethical and regulatory issues. Trends in Food Science \& Technology, 34(1), 32e43.

Coles, D., Quing, L., \& Ladikas, M. (2014). Regional approaches to innovative food technologies: Comparative case studies from Europe and China (in preparation).

Conti, J., Satterfield, T., \& Harthorn, B. H. (2011). Vulnerability and social justice as factors in emergent US nanotechnology risk perceptions. Risk Analysis, 31(11), 1734e1748.

Costa-Font, M., Gil, J. M., \& Traill, W. B. (2008). Consumer acceptance, valuation of and attitudes towards genetically modified food: review and implications for food policy. Food Policy, 33(2), 99e111.

Cvetkovich, G. (2013). Social trust and the management of risk. Routledge.

David, K., \& Thompson, P. B. (2011). What can nanotechnology learn from biotechnology?: Social and ethical lessons for nanoscience 
from the Debate Over Agrifood Biotechnology and GMOs. Academic Press, ISBN 978-0-12-373990-2.

Delgado, A., Kjølberg, K. L., \& Wickson, F. (2011). Public engagement coming of age: from theory to practice in STS encounters with nanotechnology. Public Understanding of Science, 20(6), 826e845.

DeLouise, L. A. (2012). Applications of nanotechnology in dermatology. Journal of Investigative Dermatology, 132, 964e975.

Donk, A., Metag, J., Kohring, M., \& Marcinkowski, F. (2012). Framing emerging technologies risk perceptions of nanotechnology in the German Press. Science Communication, 34(1), $5 \mathrm{e} 29$.

Dudo, A., Choi, D. H., \& Scheufele, D. A. (2011). Food nanotechnology in the news. Coverage patterns and thematic emphases during the last decade. Appetite, 56(1), 78e89.

Eiser, J. R., Miles, S., \& Frewer, L. J. (2002). Trust, perceived risk, and attitudes toward food technologies. Journal of Applied Social Psychology, 32(11), 2423e2433.

Farshchi, P., Sadrnezhaad, S. K., Nejad, N. M., Mahmoodi, M., \& Abadi, L. I. G. (2011). Nanotechnology in the public eye: the case of Iran, as a developing country. Journal of Nanoparticle Research, 13(8), 3511e3519.

Fife-Schaw, C., \& Rowe, G. (1996). Public perceptions of everyday food hazards: a psychometric study. Risk Analysis, 16(4), 487e500.

Fischer, A. R. H., van Dijk, H., de Jonge, J., Rowe, G., \& Frewer, L. J. (2013). Attitudes and attitudinal ambivalence change towards nanotechnology applied to food production. Public Understanding of Science, 22(7), 817e831.

Frewer, L. J., Bergmann, K., Brennan, M., Lion, R., Meertens, R., Rowe, G., et al. (2011a). Consumer response to novel agrifood technologies: implications for predicting consumer acceptance of emerging food technologies. Trends in Food Science \& Technology, 22(8), 442e456.

Frewer, L. J., Fischer, A. R. H., Brennan, M., B_an_ati, D., Lion, R. Meertens, R. M., et al. (2014). Risk/benefit communication about food e a systematic review of the literature. Critical Reviews in Food Science and Technology, (still in press).

Frewer, L. J., Howard, C., \& Shepherd, R. (1997). Public concerns in the United Kingdom about general and specific applications of genetic engineering: risk, benefit, and ethics. Science, Technology \& Human Values, 22(1), 98e124.

Frewer, L. J., van der Lans, I. A., Fischer, A. R., Reinders, M. J., Menozzi, D., Zhang, X., et al. (2013). Public perceptions of agri-food applications of genetic modificationea systematic review and meta-analysis. Trends in Food Science \& Technology, 30(2), 142e152.

Frewer, L. J., Miles, S., \& Marsh, R. (2002). The media and genetically modified foods: evidence in support of social amplification of risk. Risk Analysis, 22(4), 701e 711.

Frewer, L. J., Norde, W., Fischer, A., \& Kampers, F. (2011b). In Nanotechnology in the agri-food sector. John Wiley \& Sons.

Frewer, L. J., \& Salter, B. (2002). Public attitudes, scientific advice and the politics of regulatory policy: the case of BSE. Science and Public Policy, 29(2), 137e145.

Fu, J., Park, B., Siragusa, G., Jones, L., Tripp, R., Zhao, Y., et al. (2008). An Au/Si hetero-nanorod-based biosensor for salmonella detection. Nanotechnology, 19(15), 155502. http://dx.doi.org/ 10.1088/0957-4484/19/15/155502.

Gaskell, G., Allum, N., Wagner, W., Kronberger, N., Torgersen, H., Hampel, J., et al. (2004). GM foods and the misperception of risk perception. Risk Analysis, 24(1), 185e194.

Glasner, P. (2002). Beyond the genome: reconstituting the new genetics. New Genetics and Society, 21(3), 267e277.

Godfray, H. C. J., Beddington, J. R., Crute, I. R., Haddad, L., Lawrence, D., Muir, J. F., et al. (2010). Food security: the challenge of feeding 9 billion people. Science, 327(5967), $812 \mathrm{e} 818$.
Griffin, A., \& Hauser, J. R. (1993). The voice of the customer. Marketing Science, 12(1), 1e27.

Groboljsek, B., \& Mali, F. (2012). Daily newspapers' views on nanotechnology in Slovenia. Science Communication, 34(1), 30e56.

Grunwald, A. (2005). Nanotechnology d A new field of ethical inquiry? Science and Engineering Ethics, 11(2), 187e201. http:// dx.doi.org/10.1007/s11948-005-0041-0.

Gupta, N. (2013). The views of experts and the public regarding societal preferences for innovation in nanotechnology. Doctoral dissertation. Wageningen: Wageningen University, ISBN 978-94-6173-762-5.

Gupta, N., Fischer, A. R., \& Frewer, L. J. (2012). Socio-psychological determinants of public acceptance of technologies: a review. Public Understanding of Science, 21(7), 782e795.

Gupta, N., Fischer, A. R., George, S., \& Frewer, L. J. (2013). Expert views on societal responses to different applications of nanotechnology: a comparative analysis of experts in countries with different economic and regulatory environments. Journal of Nanoparticle Research, 15(8), 1e15.

Gupta, N., Fischer, A. R., van der Lans, I. A., \& Frewer, L. J. (2012). Factors influencing societal response of nanotechnology: an expert stakeholder analysis. Journal of Nanoparticle Research, 14(5), 1e15.

van Harreveld, F., Rutjens, B. T., Schneider, I. K., Nohlen, H. U., \& Keskinis, K. (2014). In doubt and disorderly: ambivalence promotes compensatory perceptions of order. Journal of Experimental Psychology: General, http://dx.doi.org/10.1037/ a0036099.

Harvey, D., \& Hubbard, C. (2013). Reconsidering the political economy of farm animal welfare: an anatomy of market failure. Food Policy, 38, 105e114.

Hingley, M., Mikkola, M., Canavari, M., \& Asioli, D. (2012). Local and sustainable food supply: the role of European retail consumer co-operatives. International Journal on Food System Dynamics, 2(4), 340e356.

Ho, S. S., Scheufele, D. A., \& Corley, E. A. (2011). Value predispositions, mass media, and attitudes toward nanotechnology: the interplay of public and experts. Science Communication, 33(2), 167e200.

Illbery, B., \& Kneafsey, M. (1998). Product and place: promoting quality products and services in the lagging rural regions of the European Union. European Urban And Regional Studies, 5(4), 329e334.

Ingram, J. S. I., Gregory, P. J., \& Izac, A. M. (2008). The role of agronomic research in climate change and food security policy. Agriculture, Ecosystems \& Environment, 126(1), 4e12.

Jayanthi, A. P., Beumer, K., \& Bhattacharya, S. (2012). Nanotechnology: 'risk Governance'in india. Economic and Political Weekly, 47(4), 34e40.

Kahan, D. M., Braman, D., Slovic, P., Gastil, J., \& Cohen, G. (2009) Cultural cognition of the risks and benefits of nanotechnology. Nature Nanotechnology, 4(2), 87e90.

Kenyon, W. (2005). A critical review of citizens' juries: how useful are they in facilitating public participation in the EU water framework directive? Journal of Environmental Planning and Management, 48(3), 431e443.

Khodakovskaya, M. V., Kim, B. S., Kim, J. N., Alimohammadi, M., Dervishi, E., Mustafa, T., et al. (2013). Carbon nanotubes as plant growth regulators: effects on tomato growth, reproductive system, and soil microbial community. Small, 9(1), 115e123. http:// dx.doi.org/10.1002/smll.201201225.

Kim, J. S., Kuk, E., Yu, K. N., Kim, J. H., Park, S. J., Lee, H. J., et al. (2007). Antimicrobial effects of silver nanoparticles. Nanomedicine: Nanotechnology, Biology, and Medicine, 3(1), 95e101. 
Please cite this article in press as: Frewer, L. J., et al., Consumer attitudes towards nanotechnologies applied to food production, Trends in Food Science \& Technology (2014), http://dx.doi.org/10.1016/j.tifs.2014.06.005 
Knight, A. J. (2009). Perceptions, knowledge and ethical concerns with GM foods and the GM process. Public Understanding of Science, 18(2), 177e188.

Kriwy, P., \& Mecking, R. A. (2012). Health and environmental consciousness, costs of behaviour and the purchase of organic food. International Journal of Consumer Studies, 36(1), 30e37.

te Kulve, H., \& Rip, A. (2011). Constructing productive engagement: pre-engagement tools for emerging technologies. Science and Engineering Ethics, 17(4), 699e714.

Kuzma, J., \& Priest, S. (2010). Nanotechnology, risk, and oversight: learning lessons from related emerging technologies. Risk Analysis, 30(11), 1688e1698.

Lagerkvist, C. J., \& Hess, S. (2011). A meta-analysis of consume willingness to pay for farm animal welfare. European Review of Agricultural Economics, 38(1), 55e78.

Lang, J. T., \& Hallman, W. K. (2005). Who does the public trust? the case of genetically modified food in the United States. Risk Analysis, 25(5), 1241e1252.

Lee, C. J., Scheufele, D. A., \& Lewenstein, B. V. (2005). Public attitudes toward emerging technologies: examining the interactive effects of cognitions and affect on public attitudes toward nanotechnology. Science Communication, 27(2), 240e267.

Liang, X., Ho, S. S., Brossard, D., Xenos, M. A., Scheufele, D. A., Anderson, A. A., et al. (2013). Value predispositions as perceptual filters: comparing of public attitudes toward nanotechnology in the United States and Singapore. Public Understanding of Science, 0963662513510858.

Lopez -V azquez, E., Brunner, T. A., \& Siegrist, M. (2012). Perceived risks and benefits of nanotechnology applied to the food and packaging sector in M exico. British Food Journal, 114(2), 197e205.

Lowe, P., Murdoch, J., Marsden, T., Munton, R., \& Flynn, A. (1993). Regulating the new rural spaces: the uneven development of land. Journal of Rural Studies, 9(3), 205e222.

Lowe, P., Phillipson, J., \& Lee, R. P. (2008). Socio-technical innovation for sustainable food chains: roles for social science. Trends in Food Science \& Technology, 19(5), $226 \mathrm{e} 233$.

Luo, P. G., Tzeng, T.-R., Qu, L., Lin, Y., Caldwell, E., Latour, R. A., et al. (2005). Quantitative analysis of bacterial aggregation mediated by bioactive nanoparticles. Journal of Biomedical Nanotechnology, 1(3), 291e296. http://dx.doi.org/10.1166/ jbn.2005.040.

Macnaghten, P., Kearnes, M. B., \& Wynne, B. (2005). Nanotechnology, governance, and public deliberation: what role for the social sciences? Science Communication, 27(2), 268e291.

Macoubrie, J. (2004). Public perceptions about nanotechnology: risks, benefits and trust. Journal of Nanoparticle Research, 6(4), 395e405.

Macoubrie, J. (2006). Nanotechnology: public concerns, reasoning and trust in government. Public Understanding of Science, 15(2), 221e241. http://dx.doi.org/10.1177/0963662506056993.

Marette, S., Roosen, J., Bieberstein, A., Blanchemanche, S., \& Vandermoere, F. (2009). Impact of environmental, societal and health information on consumers' choices for nanofood. Journal of Agricultural \& Food Industrial Organization, 7(2).

Mather, D. W., Knight, J. G., Insch, A., Holdsworth, D. K., Ermen, D. F., \& Breitbarth, T. (2011). Social stigma and consumer benefits: trade-offs in adoption of genetically modified foods. Science Communication, 1e33. http://dx.doi.org/10.1177/ 1075547011428183.

McClements, D. J., Decker, E. A., \& Weiss, J. (2007). Emulsionbased delivery systems for lipophilic bioactive components. Journal of Food Science, 72(8), R109eR124. http://dx.doi.org/10.1111/ j.1750-3841.2007.00507.x.

Metag, J., \& Marcinkowski, F. (2013). Technophobia towards emerging technologies? A comparative analysis of the media coverage of nanotechnology in Austria, Switzerland and Germany. Journalism, 15(4), 463e481.

Misselhorn, A., Aggarwal, P., Ericksen, P., Gregory, P., HornPhathanothai, L., Ingram, J., et al. (2012). A vision for attaining food security. Current Opinion in Environmental Sustainability, 4(1), 7e17.

Momin, J. K., Jayakumar, C., \& Prajapati, J. B. (2013). Potential of nanotechnology in functional foods. Emirates Journal of Food and Agriculture, 25(1), 10e19.

Moon, J. J., Huang, B., \& Irvine, D. J. (2012). Engineering nano- and microparticles to tune immunity. Advanced Materials, 24(28), 3724e3746. http://dx.doi.org/10.1002/adma.201200446.

Neethirajan, S., \& Jayas, D. S. (2011). Nanotechnology for the food and bioprocessing industries. Food and Bioprocess Technology, 4(1), 39e47. http://dx.doi.org/10.1007/s11947-010-0328-2.

Nel, A. E., Madler, L., Velegol, D., Xia, T., Hoek, E. M., Somasundaran, P., et al. (2009). Understanding biophysicochemical interactions at the nano-bio interface. Nature Materials, 8(7), 543e557. http://dx.doi.org/10.1038/nmat2442.

Nielsen, H. B., Sonne, A. M., Grunert, K. G., Banati, D., Poll_akToth,_A., Lakner, Z., et al. (2009). Consumer perception of the use of high-pressure processing and pulsed electric field technologies in food production. Appetite, 52(1), 115e126.

Nordgren, L. F., van Harreveld, F., \& van der Pligt, J. (2006). Ambivalence, discomfort, and motivated information processing. Journal of Experimental Social Psychology, 42(2), $252 \mathrm{e} 258$.

Pacurari, M., Castranova, V., \& Vallyathan, V. (2010). Single- and multi-wall carbon nanotubes versus asbestos: are the carbon nanotubes a new health risk to humans? Journal of Toxicological and Environmental Health A, 73(5), 378e395. http://dx.doi.org/ 10.1080/15287390903486527.

Petts, J. (2008). Public engagement to build trust: false hopes? Journal of Risk Research, 11(6), 821e835.

Pidgeon, N., Harthorn, B., \& Satterfield, T. (2011). Nanotechnology risk perceptions and communication: emerging technologies, emerging challenges. Risk Analysis, 31(11), 1694e1700.

Pidgeon, N., Kasperson, R. E., \& Slovic, P. (2003). The social amplification of risk. Cambridge: Cambridge University Press.

Powell, M. C., \& Colin, M. (2008). Meaningful citizen engagement in science and technology what would it really take? Science Communication, 30(1), $126 \mathrm{e} 136$.

Priest, S. H., \& Greenhalgh, T. (2011). Nanotechnology as an experiment in democracy: how do citizens form opinions about technology and policy? Journal of Nanoparticle Research, 13(4), 1521e1531.

Project on Emerging nanotechnologies. http://www.nanotechproject.

Raj, S., Jose, S., Sumod, U. S., \& Sabitha, M. (2012). Nanotechnology in cosmetics: opportunities and challenges. Journal of Pharmacy \& Bioallied Sciences, 4(3), 186.

Rajeshkumar, S., Venkatesan, C., Sarathi, M., Sarathbabu, V., Thomas, J., Anver Basha, K., et al. (2009). Oral delivery of DNA construct using chitosan nanoparticles to protect the shrimp from white spot syndrome virus (WSSV). Fish and Shellfish Immunology, 26(3), 429e437. http://dx.doi.org/10.1016/ j.fsi.2009.01.003.

Raley, M. E., Ragona, M., Sijtsema, S. J., Fischer, A. R. H., \& Frewer, L. J. (2014). Barriers to using consumer science information in food technology innovations: An exploratory study using Delphi methodology (submitted for publication).

Reisch, L. A., Scholl, G., \& Bietz, S. (2011). 'Better safe than sorry': consumer perceptions of and deliberations on nanotechnologies. International Journal of Consumer Studies, 35(6), 644e654. Renn,

O., \& Roco, M. C. (2006). Nanotechnology and the need for risk governance. Journal of Nanoparticle Research, 8(2), $153 e 191$. 
Retzbach, A., Marschall, J., Rahnke, M., Otto, L., \& Maier, M. (2011). Public understanding of science and the perception of nanotechnology: the roles of interest in science, methodological knowledge, epistemological beliefs, and beliefs about science. Journal of Nanoparticle Research, 13(12), 6231e6244. Roco,

M. C. (2003). Broader societal issues of nanotechnology. Journal of Nanoparticle Research, 5(3e4), 181e189. Rogers-

Brown, J. B., Shearer, C., \& Harthorn, B. H. (2011). From biotech to nanotech: public debates about technological modification of food. Environment and Society: Advances in Research, 2(1), 149e169. http://dx.doi.org/10.3167/ ares.2011.020109.

Rollin, F., Kennedy, J., \& Wills, J. (2011). Consumers and new food technologies. Trends in Food Science \& Technology, 22(2), 99e111.

Ronteltap, A., Fischer, A. R. H., \& Tobi, H. (2011). Societal response to nanotechnology: converging technologiesconverging societal response research? Journal of Nanoparticle Research, 13(10), 4399e4410.

Rowe, G., \& Frewer, L. J. (2005). A typology of public engagement mechanisms. Science, Technology \& Human Values, 30(2), 251e290.

Royal Society and Royal Academy of Engineering. (2004). Nanosciences and nanotechnologies: opportunities and uncertainties. London: Royal Society.

Rutsaert, P., Regan, A., Pieniak, Z., McConnon, A., Moss, A., Wall, $P$., et al. (2013). The use of social media in food risk and benefit communication. Trends in Food Science and Technology, 30(1), 84e91.

Sahin, N., \& Ekli, E. (2013). Nanotechnology awareness, opinions and risk perceptions among middle school students. International Journal of Technology and Design Education, 23(4), 867e881.

Satterfield, T., Kandlikar, M., Beaudrie, C. E., Conti, J., \& Harthorn, B. H. (2009). Anticipating the perceived risk of nanotechnologies. Nature Nanotechnology, 4(11), $752 \mathrm{e} 758$.

Scheufele, D. A., Corley, E. A., Dunwoody, S., Shih, T. J., Hillback, E., \& Guston, D. H. (2007). Scientists worry about some risks more than the public. Nature Nanotechnology, 2(12), 732e734. http:// dx.doi.org/10.1038/nnano.2007.392.

Scheufele, D. A., Corley, E. A., Shih, T. J., Dalrymple, K. E., \& Ho, S. S. (2009). Religious beliefs and public attitudes toward nanotechnology in Europe and the United States. Nature Nanotechnology, 4(2), 91e94.

Scheufele, D. A., \& Lewenstein, B. V. (2005). The public and nanotechnology: how citizens make sense of emerging technologies. Journal of Nanoparticle Research, 7(6), 659e667.

Schmidt, D. B. (2000). Consumer response to functional foods in the 21st century. AgBioForum, 3(1), 14e19.

von Schomberg, R. (2013). A vision of responsible research and innovation. Responsible Innovation, 51e74.

Schutz, $\in$ H., \& Wiedemann, P. M. (2008). Framing effects on risk perception of nanotechnology. Public Understanding of Science, 17(3), 369e379.

Seleem, M. N., Jain, N., Pothayee, N., Ranjan, A., Riffle, J. S., \& Sriranganathan, N. (2009). Targeting Brucella melitensis with polymeric nanoparticles containing streptomycin and doxycycline. FEMS Microbiology Letters, 294(1), 24e31. http:// dx.doi.org/10.1111/j.1574-6968.2009.01530.x.

Seltenrich, N. (2013). Nanosilver: weighing the risks and benefits. Environmental Health Perspectives, 121(7). http://dx.doi.org/ 10.1289/ehp.121-a220.
Senocak, E. (2014). A survey on nanotechnology in the view of the Turkish Public. Science Technology and Society, 19(1), 79 e94.

Sheetz, T., Vidal, J., Pearson, T. D., \& Lozano, K. (2005). Nanotechnology: awareness and societal concerns. Technology in Society, 27(3), 329e345.

Siegrist, M. (2008). Factors influencing public acceptance of innovative food technologies and products. Trends in Food Science and Technology, 19(11), 603e608.

Siegrist, M., Cousin, M. E., Kastenholz, H., \& Wiek, A. (2007). Public acceptance of nanotechnology foods and food packaging: the influence of affect and trust. Appetite, 49(2), 459e466.

Siegrist, M., Stampfli, N., Kastenholz, H., \& Keller, C. (2008). Perceived risks and perceived benefits of different nanotechnology foods and nanotechnology food packaging. Appetite, 51(2), 283e290.

Silvestre, C., Duraccio, D., \& Cimmino, S. (2011). Food packaging based on polymer nanomaterials. Progress in Polymer Science (Oxford), 36(12), 1766e1782.

Smith, S. E. S., Hosgood, H. D., Michelson, E. S., \& Stowe, M. H. (2008). Americans' nanotechnology risk perception. Journal of Industrial Ecology, 12(3), 459e473.

Sorenson, D., \& Henchion, M. (2011). Understanding consumers' cognitive structures with regard to high pressure processing: a means-end chain application to the chilled ready meals category. Food Quality and Preference, 22(3), 271e280.

Stampfli, N., Siegrist, M., \& Kastenholz, H. (2010). Acceptance of nanotechnology in food and food packaging: a path model analysis. Journal of Risk Research, 13(3), 353e365.

Stemerding, D., \& Rerimassie, V. (2013). Discourses on sSynthetic Biolology in Europe. Working Paper 1305. Den Haag: Rathenau Instituut.

Subramanian, A., Kirwan, K., \& Pink, D. (2010). Food security: perception failure. Science, 328(5975), 173.

Svagan, A. J., Hedenqvist, M. S., \& Berglund, L. (2009). Reduced water vapour sorption in cellulose nanocomposites with starch matrix. Composites Science and Technology, 69(3e4), 500e506.

Swierstra, T., \& Rip, A. (2007). Nano-ethics as NEST-ethics: patterns of moral argumentation about new and emerging science and technology. Nanoethics, 1(1), 3e20.

Torgersen, H. (2009). Synthetic biology in society: learning from past experience? Systems and Synthetic Biology, 3(1e4), 9e17.

Van Kleef, E., van Trijp, H. C. M., \& Luning, P. (2005). Consumer research in the early stages of new product development: a critical review of methods and techniques. Food Quality and Preference, 16(3), 181e201.

Vandermoere, F., Blanchemanche, S., Bieberstein, A., Marette, S., \& Roosen, J. (2011). The public understanding of nanotechnology in the food domain the hidden role of views on science, technology, and nature. Public Understanding of Science, 20(2), 195e206.

Wang, X. F., Zhang, S. L., Zhu, L. Y., Xie, S. Y., Dong, Z., Wang, Y., et al. (2012). Enhancement of antibacterial activity of tilmicosin against Staphylococcus aureus by solid lipid nanoparticles in vitro and in vivo. Veterinary Journal, 191(1), 115e120.

Yawson, R. M., \& Kuzma, J. (2010). Systems mapping of consumer acceptance of agrifood nanotechnology. Journal of Consumer Policy, 33(4), 299 e322. 
Please cite this article in press as: Frewer, L. J., et al., Consumer attitudes towards nanotechnologies applied to food production, Trends in Food Science \& Technology (2014), http://dx.doi.org/10.1016/j.tifs.2014.06.005 


\begin{tabular}{|c|c|c|c|c|c|c|c|c|}
\hline of application & $\begin{array}{l}\text { Nanomaterial } \\
\text { s used }\end{array}$ & $\begin{array}{l}\text { Commercial } \\
\text { product/industr } \\
\text { y }\end{array}$ & $\begin{array}{l}\text { Scientific and commercial } \\
\text { rational }\end{array}$ & $\begin{array}{l}\text { Risk issues } \\
\text { perceived by } \\
\text { consumers }\end{array}$ & $\begin{array}{l}\text { Benefit } \\
\text { issues as } \\
\text { perceived } \\
\text { by } \\
\text { consumer } \\
\text { s }\end{array}$ & $\begin{array}{l}\text { Ethical issues of } \\
\text { relevance to } \\
\text { consumer } \\
\text { acceptance }\end{array}$ & $\begin{array}{l}\text { Uncertainty } \\
\text { and } \\
\text { governance }\end{array}$ & Key references \\
\hline $\begin{array}{l}\text { Animal } \\
\text { nutrition }\end{array}$ & $\begin{array}{l}\text { Nano- } \\
\text { emulsions for } \\
\text { delivery of } \\
\text { micronutrients } \\
\text { and minerals } \\
\text { (1) } \\
\text { Biopolymeric } \\
\text { Nanoparticles } \\
\text { (2) }\end{array}$ & $\begin{array}{l}\text { Aquapowr } \\
\text { (Nanomaterials } \\
\text { of nutrient) }{ }^{1} \\
\text { MesoZinc }^{\mathrm{TM}}\end{array}$ & $\begin{array}{l}\text { Enzymes delivered through } \\
\text { nano-emulsion enhance } \\
\text { feed conversion } \\
\text { Enhanced absorption and } \\
\text { bioavailability of nutrients, } \\
\text { Enhanced solubility } \\
\text { and disperse-ability of } \\
\text { lipophilic nutrients in } \\
\text { aqueous-based systems } \\
\text { Controlled and sustained } \\
\text { release }\end{array}$ & $\begin{array}{l}\text { Exposure to } \\
\text { nanomaterials } \\
\text { or their } \\
\text { residues } \\
\text { present in } \\
\text { animal } \\
\text { products } \\
\text { Environmental } \\
\text { impact of } \\
\text { waste and } \\
\text { excreted } \\
\text { nanomaterials }\end{array}$ & $\begin{array}{l}\text { Reduced } \\
\text { cost } \\
\text { Animal } \\
\text { welfare }\end{array}$ & $\begin{array}{l}\text { Transparency on } \\
\text { the use of } \\
\text { nanomaterials to } \\
\text { enable decision } \\
\text { making on } \\
\text { purchase } \\
\text { Potential benefit to } \\
\text { producers alone } \\
\text { Animal ethics }\end{array}$ & $\begin{array}{l}\text { Potential health } \\
\text { issues in } \\
\text { consumers and } \\
\text { farm workers } \\
\text { exposed to } \\
\text { nanomaterials. } \\
\text { Regulating the } \\
\text { use of } \\
\text { nanomaterials in } \\
\text { agriculture } \\
\text { Benefit sharing } \\
\text { among different } \\
\text { stakeholders }\end{array}$ & $\begin{array}{l}\text { (1) McClements DJ, Weiss J, Decker EA. Emulsion-basec } \\
\text { delivery systems for lipoliphic bioactive components. } J \\
\text { Food Sci. 2007;72(8): R109-R124. } \\
\text { (2) Chaudhry, Q., M. Scotter, J. Blackburn, B. Ross, } \\
\text { A. Boxall, L. Castle, R. Aitken and R. } \\
\text { Watkins. 2008. Applications and implications } \\
\text { of nanotechnologies for the food sector. Food } \\
\text { Additives Cont. 25(3):241-258 }\end{array}$ \\
\hline
\end{tabular}




\begin{tabular}{|c|c|c|c|c|c|c|c|c|}
\hline & & & & & & & & Nanotechnology. 2008, 19:155502. \\
\hline $\begin{array}{l}\text { Vaccine } \\
\text { delivery }\end{array}$ & $\begin{array}{l}\text { Biodegradable } \\
\text { nanoparticles } \\
(8),(9) \\
\text { Chitosan (10) }\end{array}$ & & $\begin{array}{l}\text { Convenient delivery (through } \\
\text { oral route) } \\
\text { Long-term protection }\end{array}$ & $\begin{array}{l}\text { Possible } \\
\text { exposure to } \\
\text { vaccine } \\
\text { components } \\
\text { because of the } \\
\text { prevalence of } \\
\text { nanomaterials }\end{array}$ & $\begin{array}{l}\text { Reduced } \\
\text { cost } \\
\text { Biologicall } \\
\text { y safer } \\
\text { animal } \\
\text { products } \\
\text { Animal } \\
\text { welfare }\end{array}$ & $\begin{array}{l}\text { Transparency on } \\
\text { the use of } \\
\text { nanomaterials to } \\
\text { enable decision } \\
\text { making on } \\
\text { purchase } \\
\text { Potential benefit to } \\
\text { producers alone } \\
\text { Animal ethics }\end{array}$ & $\begin{array}{l}\text { Environmental } \\
\text { issues related to } \\
\text { uncontrolled use } \\
\text { and release of } \\
\text { nanomaterials }\end{array}$ & $\begin{array}{l}\text { (8) Takami Akagi, Masanori Baba, Mitsuru Akashi. } \\
\text { Biodegradable Nanoparticles as Vaccine Adjuvants } \\
\text { and Delivery Systems: Regulation of Immune } \\
\text { Responses by Nanoparticle-Based Vaccine. } \\
\text { Advances in Polymer Science,v. 247, p. 31-64, } \\
2012 \\
\text { (9). . J. Moon, B. Huang, and D. J. Irvine, } \\
\text { "Engineering nano- and microparticles to tune } \\
\text { immunity," Advanced Materials, vol. 24, no. 28, pp. } \\
\text { 3724-3746, 2012. } \\
\text { (10) Rajeshkumar S, Venkatesan C, Sarathi M, } \\
\text { Sarathbabu V, Thomas J, Anver Basha K, Sahul } \\
\text { Hameed AS. Oral delivery of DNA construct using } \\
\text { chitosan nanoparticles to protect the shrimp from } \\
\text { white spot syndrome virus (WSSV). Fish \& Shellfish } \\
\text { Immunology } 26 \text { (2009) 429-437 }\end{array}$ \\
\hline $\begin{array}{l}\text { Animal } \\
\text { nutrition }\end{array}$ & $\begin{array}{l}\text { Nanoemuslion } \\
\text { for delivery of } \\
\text { micro-nutrients } \\
(2)\end{array}$ & $\begin{array}{l}\text { Purest Colloids, } \\
\text { Inc. }\end{array}$ & Instant nutrient absorption & $\begin{array}{l}\text { Presence of } \\
\text { nanomaterial } \\
\text { residues in } \\
\text { end food } \\
\text { products } \\
\text { Environmental } \\
\text { impact of } \\
\text { waste and } \\
\text { excreted } \\
\text { nanomaterials }\end{array}$ & $\begin{array}{l}\text { Reduced } \\
\text { cost }\end{array}$ & $\begin{array}{l}\text { Transparency on } \\
\text { the use of } \\
\text { nanomaterials to } \\
\text { enable decision } \\
\text { making on } \\
\text { purchase } \\
\text { Potential benefit to } \\
\text { producers alone }\end{array}$ & $\begin{array}{l}\text { Unknown } \\
\text { biological } \\
\text { consequences in } \\
\text { animals and } \\
\text { consumers }\end{array}$ & $\begin{array}{l}\text { (2) Chaudhry, Q., M. Scotter, J. Blackburn, B. Ross, } \\
\text { A. Boxall, L. Castle, R. Aitken and R. } \\
\text { Watkins. 2008. Applications and implications } \\
\text { of nanotechnologies for the food sector. Food } \\
\text { Additives Cont. 25(3):241-258 }\end{array}$ \\
\hline $\begin{array}{l}\text { Plant } \\
\text { nutrition }\end{array}$ & $\begin{array}{l}\text { Nanoemulsion } \\
(11) \\
\text { Carbon } \\
\text { nanotube } \\
(\mathrm{CNT})(12)\end{array}$ & $\begin{array}{l}\text { Primo MAXX } \\
\text { Plant Growth } \\
\text { Regulator, } \\
\text { Syngenta, } \\
\text { Switzerland } \\
\\
\text { Nano-Gro }{ }^{\mathrm{TM}} \\
\text { (Nanomaterial } \\
\text { for modulating } \\
\text { plant signal) }\end{array}$ & $\begin{array}{l}\text { Instant nutrient absorption } \\
\text { by plants } \\
\text { CNTs increases production } \\
\text { by modulating soil bacteria } \\
\text { population }\end{array}$ & $\begin{array}{l}\text { Presence of } \\
\text { nanomaterial } \\
\text { residues in } \\
\text { end food } \\
\text { products }\end{array}$ & $\begin{array}{l}\text { Reduced } \\
\text { cost }\end{array}$ & $\begin{array}{l}\text { Transparency on } \\
\text { the use of } \\
\text { nanomaterials to } \\
\text { enable decision } \\
\text { making on } \\
\text { purchase } \\
\text { Potential benefit to } \\
\text { producers alone }\end{array}$ & $\begin{array}{l}\text { Unknown } \\
\text { environmental } \\
\text { consequences } \\
\text { Human and } \\
\text { environmental } \\
\text { health risk } \\
\text { posed by CNTs } \\
\text { (13) }\end{array}$ & $\begin{array}{l}\text { (11) Lynn J. Frewer, Willem Norde, Arnout Fischer, } \\
\text { Frans Kampers. Nanotechnology in the Agri-Food } \\
\text { Sector. Wiley, } 2011 . \\
\text { (12) Khodakovskaya MV, Kim BS, Kim JN, } \\
\text { Alimohammadi M, Dervishi E, Mustafa T, Cernigla } \\
\text { CE. Carbon nanotubes as plant growth regulators: } \\
\text { effects on tomato growth, reproductive system, and } \\
\text { soil microbial community. Small. } 2013 \text { Jan } \\
\text { 14;9(1):115-23. } \\
\text { (13) Pacurari M, Castranova V, Vallyathan V. Single- } \\
\text { and multi-wall carbon nanotubes versus asbestos: } \\
\text { are the carbon nanotubes a new health risk to } \\
\text { humans? J Toxicol Environ Health A. } \\
\text { 2010;73(5):378-95. }\end{array}$ \\
\hline
\end{tabular}




\begin{tabular}{|c|c|c|c|c|c|c|c|c|}
\hline $\begin{array}{l}\text { Smart } \\
\text { pesticides }\end{array}$ & $\begin{array}{l}\text { Nanoemulsion } \\
\text { S, Metallic } \\
\text { nanoparticles } \\
(14)\end{array}$ & $\begin{array}{l}\text { MAXIDE } ® \\
\text { fungicide from } \\
\text { Syngenta, } \\
\text { Switzerland } \\
\text { Bayer Crop } \\
\text { Science, } \\
\text { Germany } \\
\text { BASF, } \\
\text { Germany }\end{array}$ & $\begin{array}{l}\text { Increased surface area of } \\
\text { pesticide reduces the } \\
\text { application rate and rapid } \\
\text { activity. } \\
\text { Resistant to wash off by rain }\end{array}$ & $\begin{array}{l}\text { Presence of } \\
\text { nanomaterial } \\
\text { residues in } \\
\text { end food } \\
\text { products } \\
\text { Environmental } \\
\text { impact of use } \\
\text { of } \\
\text { nanomaterials }\end{array}$ & $\begin{array}{l}\text { Reduced } \\
\text { cost }\end{array}$ & $\begin{array}{l}\text { Transparency on } \\
\text { the use of } \\
\text { nanomaterials to } \\
\text { enable decision } \\
\text { making on } \\
\text { purchase } \\
\text { Potential benefit to } \\
\text { producers alone }\end{array}$ & $\begin{array}{l}\text { Unknown } \\
\text { environmental } \\
\text { consequences }\end{array}$ & $\begin{array}{l}\text { (14) C.R. Chinnamuthu , P. Murugesa Boopathi. } \\
\text { Nanotechnology and Agroecosystem. Madras } \\
\text { Agriculture Journal 2009, } 96(1-6): 17-31 .\end{array}$ \\
\hline $\begin{array}{l}\text { Food } \\
\text { contact } \\
\text { materials }\end{array}$ & $\begin{array}{l}\text { Nano-Silver } \\
\text { Nano- } \\
\text { Ceramics (15) }\end{array}$ & $\begin{array}{l}\text { Antibacterial } \\
\text { Kitchenware } \\
\text { from Nano Care } \\
\text { Technology, Ltd } \\
\text { Bialetti® } \\
\text { Aeternum Saute } \\
\text { Pan }\end{array}$ & $\begin{array}{l}\text { Prevent bacterial growth on } \\
\text { the surface of food contact } \\
\text { materials } \\
\text { Enhance the heat transfer in } \\
\text { cooking utensils }\end{array}$ & $\begin{array}{l}\text { Presence of } \\
\text { nanomaterial } \\
\text { residues in } \\
\text { end food } \\
\text { products } \\
\text { Environmental } \\
\text { impact of } \\
\text { waste } \\
\text { nanomaterials }\end{array}$ & $\begin{array}{l}\text { Biologicall } \\
\text { y safer } \\
\text { food } \\
\text { Hygienic } \\
\text { handling } \\
\text { of food }\end{array}$ & $\begin{array}{l}\text { Transparency on } \\
\text { the use of } \\
\text { nanomaterials to } \\
\text { enable decision } \\
\text { making on } \\
\text { purchase }\end{array}$ & $\begin{array}{l}\text { Environmental } \\
\text { health issues } \\
\text { related to } \\
\text { release of silver } \\
(16)\end{array}$ & $\begin{array}{l}\text { (15) Project on Emerging nanotechnologies } \\
\text { http://www.nanotechproject } \\
\text { (16) Nate Seltenrich. Nanosilver: Weighing the Risks } \\
\text { and Benefits. Environ Health Perspect; } 2013 \\
\text { 121(7):A220-5. }\end{array}$ \\
\hline $\begin{array}{l}\text { Food } \\
\text { additives }\end{array}$ & $\begin{array}{l}\mathrm{TiO}_{2}, \mathrm{SiO}_{2} \\
\text { Nanocellulose } \\
\text { (15) }\end{array}$ & $\begin{array}{l}\text { Dairy products, } \\
\text { chocolates, } \\
\text { spice powder }\end{array}$ & $\begin{array}{l}\text { Anti-caking agent } \\
\text { Favourable texture and } \\
\text { appearance }\end{array}$ & $\begin{array}{l}\text { Potential } \\
\text { exposure to } \\
\text { nanomaterials } \\
\text { Bioaccumulati } \\
\text { on of } \\
\text { nanomaterials }\end{array}$ & $\begin{array}{l}\text { Better } \\
\text { quality of } \\
\text { end food } \\
\text { product } \\
\text { Enhanced } \\
\text { organolept } \\
\text { ic } \\
\text { properties }\end{array}$ & $\begin{array}{l}\text { Labelling of food } \\
\text { products produced } \\
\text { through } \\
\text { nanotechnology } \\
\text { application so as } \\
\text { to enable the } \\
\text { consumers to } \\
\text { make decision on } \\
\text { purchasing }\end{array}$ & $\begin{array}{l}\text { Unknown health } \\
\text { risk of } \\
\text { nanomaterials } \\
\text { to consumer } \\
\text { (17) } \\
\text { Unknown health } \\
\text { environmental } \\
\text { issues }\end{array}$ & $\begin{array}{l}\text { (17). Nel, A. E.; Mädler, L.; Velegol, D.; Xia, T.; } \\
\text { Hoek, E. M. V.; Somasundaran, P.; Klaessig, F.; } \\
\text { Castranova, V.; Thompson, M. Understanding } \\
\text { Biophysicochemical Interactions at The Nano-Bio } \\
\text { Interface. Nat. Mater. } 2009,8,543-557 .\end{array}$ \\
\hline
\end{tabular}




\begin{tabular}{|c|c|c|c|c|c|c|c|c|}
\hline $\begin{array}{l}\text { Packaging } \\
\text { application }\end{array}$ & $\begin{array}{l}\text { Nanomaterials } \\
\text { of clay (18), } \\
\text { zinc oxide, } \\
\text { titanium } \\
\text { dioxide, silicon } \\
\text { dioxide, silver } \\
\text { (19) and } \\
\text { cellulose (20) }\end{array}$ & $\begin{array}{l}\text { Imperm } ® \\
\text { from Nanocor® } \\
\text { Inc. } \\
\text { Aegis } ₫ \text { OX from } \\
\text { Honeywell } \\
\text { Durethan_KU2- } \\
2601 \text { (Bayer AG) } \\
\text { Plastic wrapping } \\
\text { from SongSing } \\
\text { Nano } \\
\text { Technology Co. } \\
\text { Ltd } \\
\text { Melitta, } \\
\text { Germany, } \\
\text { Sharper Image } ®\end{array}$ & $\begin{array}{l}\text { Enhanced mechanical } \\
\text { properties } \\
\text { Superior barrier to the } \\
\text { permeability of oxygen and } \\
\text { water vapour } \\
\text { Increased glass transition } \\
\text { and thermal degradation } \\
\text { temperatures } \\
\text { Antimicrobial and antifungal } \\
\text { surfaces. }\end{array}$ & $\begin{array}{l}\text { Potential } \\
\text { exposure to } \\
\text { nanomaterials } \\
\text { migrating to } \\
\text { stored food } \\
\text { Environmental } \\
\text { impact of } \\
\text { waste } \\
\text { nanomaterials }\end{array}$ & $\begin{array}{l}\text { Freshness } \\
\text { of food } \\
\text { (beer, fruit } \\
\text { juices, } \\
\text { vegetable } \\
\text { oil) }\end{array}$ & $\begin{array}{l}\text { Labelling to } \\
\text { indicate the use of } \\
\text { nanotechnology } \\
\text { products }\end{array}$ & $\begin{array}{l}\text { Unknown health } \\
\text { risk of } \\
\text { nanomaterials } \\
\text { to consumer } \\
\text { (17), (19) } \\
\text { Unknown health } \\
\text { environmental } \\
\text { issues related to } \\
\text { the waste } \\
\text { disposal (21) }\end{array}$ & $\begin{array}{l}\text { (18) Daniel Adame, Gary W. Beall. Direct } \\
\text { measurement of the constrained polymer region in } \\
\text { polyamide/clay nanocomposites and the implications } \\
\text { for gas diffusion. Applied Clay Science 2009, } 42 \\
545-552 \text {. } \\
\text { (19). Qasim Chaudhry, Michael Scotter, James } \\
\text { Blackburn , Bryony Ross, Alistair Boxall, } \\
\text { Laurence Castle, Robert Aitken, Richard Watkins. } \\
\text { Applications and implications of nanotechnologies } \\
\text { for the food sector. Food Additives and } \\
\text { Contaminants 2008; } 25(3) \text { : } 241-258 \\
\text { (20). Anna J. Svagan, Mikael S. Hedenqvist, Lars } \\
\text { Berglund. Reduced water vapour sorption in } \\
\text { cellulose nanocomposites with starch matrix. } \\
\text { Composites Science and Technology 2009, 69(3-4) } \\
500-506 \text {. } \\
\text { (21) Clara Silvestre *, Donatella Duraccio, Sossio } \\
\text { Cimmino. Food packaging based on polymer } \\
\text { nanomaterials. Progress in Polymer Science 2011, } \\
36,1766-1782\end{array}$ \\
\hline & $\begin{array}{l}\text { Zeolite (15) } \\
\text { Silica (15) } \\
\text { Nanoencapsul } \\
\text { ation (19) } \\
\text { Nanoemulsion } \\
\text { Copper, } \\
\text { Zinc oxide (15) } \\
\text { Mg and Ca } \\
\text { (15) } \\
\text { Biopolymeric } \\
\text { Nanoparticles } \\
\text { (22) }\end{array}$ & $\begin{array}{l}\text { OilFresh }^{\mathrm{TM}} \\
\text { Aerosil }^{\mathrm{T}} \\
\text { MultiSal }^{\mathrm{TM}} \\
\text { Fabuless }^{\circledR} \\
\text { NovaSOL } \\
\text { LifePak® Nano } \\
\text { NanoCurcuminoi } \\
\text { ds }^{\mathrm{TM}} \text {, } \\
\text { NanoResveratrol } \\
\text { TM } \\
\text { Genceutica } \\
\text { Naturals } \\
\text { NanoceuticalsT } \\
\text { M (RBC } \\
\text { Life Sciences } ®)\end{array}$ & $\begin{array}{l}\text { Enhanced 'freshness' of } \\
\text { food ingredient (e.g. } \\
\text { OilFresh) } \\
\text { Increases the flow of spice } \\
\text { powder (e.g. Aerosil) } \\
\text { Improved stability and } \\
\text { controlled release of } \\
\text { ingredients (nanoemulsions) } \\
\text { A nanoemulsion that delays } \\
\text { digestion until lower regions } \\
\text { of the small intestine, } \\
\text { stimulating satiety and } \\
\text { reduce food/feed intake (e.g. } \\
\text { LifePak) } \\
\text { Enhances the solubilisation } \\
\text { and bioavailability of } \\
\text { nutrients (e.g. } \\
\text { NanoResveratrol }{ }^{\mathrm{TM}} \text { ) }\end{array}$ & $\begin{array}{l}\text { Direct } \\
\text { exposure to } \\
\text { nanomaterials }\end{array}$ & $\begin{array}{l}\text { Freshness } \\
\text { of food } \\
\text { Added } \\
\text { nutrient } \\
\text { value } \\
\text { Reduced } \\
\text { cost }\end{array}$ & $\begin{array}{l}\text { Unknown } \\
\text { exposure to } \\
\text { nanomaterials } \\
\text { Limited knowledge } \\
\text { about risk and } \\
\text { benefits of } \\
\text { nanotechnology to } \\
\text { make a decision } \\
\text { on purchase }\end{array}$ & $\begin{array}{l}\text { Unknown health } \\
\text { risk of } \\
\text { nanomaterials } \\
\text { to consumer } \\
\text { (17), (19) } \\
\text { Unknown health } \\
\text { environmental } \\
\text { issues related to } \\
\text { the waste } \\
\text { disposal (21) }\end{array}$ & $\begin{array}{l}\text { (22). Jafarali K. Momin, Chitra Jayakumar, Jashbhai } \\
\text { B. Prajapati. Potential of nanotechnology in } \\
\text { functional foods. Emir. J. Food Agric. 2013. } 25 \text { (1): } \\
\text { 10-19. }\end{array}$ \\
\hline
\end{tabular}


